\title{
Is vulnerability segmentation at the leaf-stem transition a drought resistance mechanism? A theoretical test with a trait-based model for Neotropical canopy tree species
}

\author{
Sébastien Levionnois ${ }^{1,2}$ D $\cdot$ Camille Ziegler $^{1,3} \cdot$ Patrick Heuret $^{1,2} \cdot$ Steven Jansen $^{4} \cdot$ Clément Stahl $^{1} \cdot$ Emma Calvet $^{1}$. \\ Jean-Yves Goret ${ }^{1}$ • Damien Bonal ${ }^{3}$. Sabrina Coste ${ }^{1}$
}

Received: 11 March 2021 / Accepted: 28 July 2021 / Published online: 5 October 2021

(C) The Author(s) 2021

\begin{abstract}
Key message Leaf-stem vulnerability segmentation predicts lower xylem embolism resistance in leaves than stem. However, although it has been intensively investigated these past decades, the extent to which vulnerability segmentation promotes drought resistance is not well understood. Based on a trait-based model, this study theoretically supports that vulnerability segmentation enhances shoot desiccation time across 18 Neotropical tree species.

Context Leaf-stem vulnerability segmentation predicts lower xylem embolism resistance in leaves than stems thereby preserving expensive organs such as branches or the trunk. Although vulnerability segmentation has been intensively investigated these past decades to test its consistency across species, the extent to which vulnerability segmentation promotes drought resistance is not well understood.

Aims We investigated the theoretical impact of the degree of vulnerability segmentation on shoot desiccation time estimated with a simple trait-based model.

Methods We combined data from 18 tropical rainforest canopy tree species on embolism resistance of stem xylem (flowcentrifugation technique) and leaves (optical visualisation method). Measured water loss under minimum leaf and bark conductance, leaf and stem capacitance, and leaf-to-bark area ratio allowed us to calculate a theoretical shoot desiccation time $\left(t_{\text {crit }}\right)$.

Results Large degrees of vulnerability segmentation strongly enhanced the theoretical shoot desiccation time, suggesting vulnerability segmentation to be an efficient drought resistance mechanism for half of the studied species. The difference between leaf and bark area, rather than the minimum leaf and bark conductance, determined the drastic reduction of total transpiration by segmentation during severe drought.

Conclusion Our study strongly suggests that vulnerability segmentation is an important drought resistance mechanism that should be better taken into account when investigating plant drought resistance and modelling vegetation. We discuss future directions for improving model assumptions with empirical measures, such as changes in total shoot transpiration after leaf xylem embolism.
\end{abstract}

Keywords Tropical trees $\cdot$ Vulnerability segmentation $\cdot$ Leafy shoot $\cdot$ Leaf-stem transition $\cdot$ Desiccation time $\cdot$ Drought resistance

\section{Introduction}

Handling Editor: Maurizio Mencuccini

This paper is the first article of the new topical collection on

"Trees, forests and water : resistance and resilience to water deficits"

Patrick Heuret and Sabrina Coste are joint senior authors.

Extended author information available on the last page of the article
The increasing frequency of extreme drought events due to climate change induces global tree mortality and forest dieback (Allen et al. 2010; Aleixo et al. 2019; Brodribb et al. 2020). Current climate predictions suggest drought and mortality phenomena to increase in space and time (Duffy et al. 2015), probably leading to significant impacts on forest species composition, their functioning, and productivity 
(Brienen et al. 2015, 2020; Esquivel-Muelbert et al. 2019). This situation urges a better understanding of the mechanisms underlying drought-induced tree mortality, and also the possibility to quantify and predict tree drought resistance (McDowell et al. 2018; Brodribb et al. 2020). The field of plant hydraulics can contribute to this discussion because water transport and storage in plants are tightly coupled with photosynthesis and growth. In particular, hydraulic failure of the water transport system due to high water stress is now recognised as one of main causes of drought-induced tree mortality (Urli et al. 2013; Martin-StPaul et al. 2017; Blackman et al. 2019b; Brodribb et al. 2020). Other hydraulic traits related to water absorption and rooting depth, transpiration control, and water storage have been identified in shaping drought resistance of plants (Blackman et al. 2016; Martin-StPaul et al. 2017; Brum et al. 2019). However, we still lack a clear understanding of how various drought resistance traits determine drought resistance in a complementary way.

\subsection{Quantifying plant drought resistance}

Plant drought resistance is usually defined as the desiccation time between the onset of water stress with stomatal closure, various stages of tissue dehydration, and eventually mortality (Blackman et al. 2016; Volaire 2018). This definition emphasises on the maximisation of survival during one particular water shortage, and can be simply quantified as the time between the onset of a water stress and plant death by desiccation, i.e. desiccation time. All the traits enabling the expansion of this desiccation time can be considered as drought resistance mechanisms. The plant water status is controlled by stomata, and stomatal closure is generally the first plant response to water stress (Martin-StPaul et al. 2017). Comparison of stomatal closure point across species is allowed by measuring the leaf water potential inducing ca. 90-95\% loss of maximum stomatal conductance ( $\left.\Psi_{\text {closure }} ; \mathrm{MPa}\right)$. The earlier the stomatal closure, the slower the reduction in xylem water potential (Martin-StPaul et al. 2017). An excessive water potential drop of the xylem can cause embolism (i.e. bubble formation within conduits). Embolism blocks water transport through conduits, and accumulation of embolism drives the loss of xylem hydraulic conductivity (Tyree and Sperry 1989), finally leading to plant death by desiccation (Urli et al. 2013). Drought-induced xylem embolism resistance is quantified by measuring the xylem pressure at which a certain percentage of xylem hydraulic conductivity is lost. For comparison across plant species or individuals, the xylem water potential inducing 50\% loss of xylem hydraulic conductivity $\left(\mathrm{P}_{50} ; \mathrm{MPa}\right)$ is generally used as a reference (Choat et al. 2012). Desiccation time is theoretically maximised by more negative $P_{50}$ values, and a large difference between $\Psi_{\text {closure }}$ and $P_{50}$, i.e. the stomatalhydraulic safety margin (SHSM; MPa). Earlier hydraulic studies have largely focused on xylem embolism resistance, and allowed to demonstrate that $\mathrm{P}_{50}$ is tightly related to drought mortality and drought resistance in controlled experiments (Resco et al. 2009; Brodribb and Cochard 2009; Urli et al. 2013; Blackman et al. 2019a).

The desiccation time between $\Psi_{\text {closure }}$ and $P_{50}$ is influenced by water pools stored in plant tissues, and by residual water losses (through leaves and bark) which determine the rate of depletion of these plant water reservoirs. These processes are analogical to a source-sink model. Indeed, when stomata close, leaf transpiration is not null. The leaf has a certain permeability, and closed stomata could still lose water via transpiration, which determines minimum leaf conductance $\left(g_{\text {min }} ; \mathrm{mmol} \mathrm{m}^{-2} \mathrm{~s}^{-1}\right.$; Duursma et al. 2019). The bark is equally prone to transpiration, because of an incomplete permeability of the different tissue layers that constitute the bark (Roth 1981), or lenticels, which affect drought resistance (Wolfe 2020). However, quantification of bark conductance $\left(g_{\text {bark }} ; \mathrm{mmol} \mathrm{m}^{-2} \mathrm{~s}^{-1}\right)$ across species remains scarce, particularly in the perspective of drought resistance (Blackman et al., 2019b; but see Wolfe, 2020). Overall, the lower the minimum conductance of the bark and leaves, the longer the desiccation time. The plant water reservoirs, on the other hand, are determined by tissue capacitance $(W$; $\mathrm{kg} \mathrm{m}^{-3} \mathrm{MPa}^{-1}$ ), which measures the capacity of a tissue to release water per unit of tissue volume and per unit of pressure drop (Tyree and Ewers 1991). The capacitance is determined by the empty space per unit of tissue volume, thus $W$ is strongly related to tissue density (Scholz et al. 2011; Jupa et al. 2016; Santiago et al. 2018). Since the product of $g_{\min }$ and total leaf area determines the whole-plant minimum transpiration $\left(E_{\min } ; \mathrm{mmol} \mathrm{s}^{-1}\right)$ after stomatal closure, and the product of $W$ and the volume of wood or stem determines the total capacity $\left(C ; \mathrm{kg} \mathrm{MPa}^{-1}\right)$, it can be hypothesised that the ratio between total leaf area and stem volume could have a strong functional significance regarding desiccation time.

Desiccation time can be experimentally quantified as the time between the onset of water stress and death of an entire plant or a plant organ (e.g. a branch, a leaf). This approach is relatively easy to implement in controlled experiments such as in greenhouses, where desiccation time has been demonstrated to be high for drought-resistant species (Urli et al., 2013; Li et al., 2016; Blackman et al., 2019a,b). However, observation of desiccation time is hardly feasible in natural conditions, especially for trees. To better predict desiccation time in the field, Blackman et al. (2016) have recently developed a trait-based model, integrating the drought resistance traits described above $\left(P_{50}, \Psi_{\text {closure }}, g_{\text {min }}, W\right)$. The model calculates desiccation time $\left(t_{\text {crit }}\right.$; hrs $)$ as the ratio between (1) the total amount of water releasable by tissues across the water potential drop from $\Psi_{\text {closure }}$ to critical levels of 
embolism $\left(P_{\text {crit }} ; \mathrm{MPa}\right)$ and (2) the rate of transpiration after stomatal closure, such as:

$t_{\text {crit }}=\frac{\left(\Psi_{\text {closure }}-P_{\text {crit }}\right) * W * V_{\text {plant }}}{g_{\min } * M_{H 20} * 3600 * 2 A_{L} * V P D}$

where $t_{\text {crit }}(\mathrm{h})$ is the desiccation time, $\Psi_{\text {closure }}$ is the leaf water potential at stomatal closure (MPa), $W$ is the tissue capacitance $\left(\mathrm{kg} \mathrm{m}^{-3} \mathrm{MPa}^{-1}\right), g_{\min }$ is the minimum leaf conductance $\left(\mathrm{mmol} \mathrm{m}^{-2} \mathrm{~s}^{-1}\right), M_{\mathrm{H} 20}$ is the water molar mass of $18.015 \times 10^{-6} \mathrm{~kg} \mathrm{mmol}^{-1}, V_{\text {plant }}\left(\mathrm{m}^{3}\right)$ is the volume of plant tissue releasing water, $A_{\mathrm{L}}\left(\mathrm{m}^{2}\right)$ is the total leaf area, and VPD is the vapour pressure deficit $\left(\mathrm{mol} \mathrm{mol}^{-1}\right)$. The factor 3600 converts seconds in hours. The total leaf area is multiplied by two because leaf minimum transpiration-determined by $g_{\min }$ - occurs at both abaxial and adaxial leaf sides. Blackman et al. (2019b) found a strong relationship between observed and calculated $t_{\text {crit }}$ across eight Eucalyptus species, in an experiment based on potted individuals, strengthening this trait-based model approach. This framework is promising for exploring the relative importance of mechanisms behind drought resistance, as well as the diversity of drought resistance strategies.

\subsection{Vulnerability segmentation and drought resistance}

Vulnerability segmentation has long been hypothesised to have a role in plant drought resistance (Tyree and Zimmermann 2002). The vulnerability segmentation hypothesis (VSH) predicts distal organs such as leaves and roots to be more vulnerable to xylem embolism relative to perennial organs such as the trunk or branches of a tree. One implicit implication of the preservation of perennial organs is that survival time is enhanced. The a posteriori metaphor of "safety valves" or "safety fuse" has more explicitly presented the VSH as a potential mechanism related to drought resistance (Chen et al. 2009, 2010). At the leaf-stem transition, the transpiration flow is directly proportional to leaf area. Then, a decrease in the evaporative leaf area following the rupture of the leaf water column through drought-induced leaf xylem embolism can alleviate the water potential drop in the stem during drought. In other words, the relative contribution of minimum leaf transpiration decreases with the accumulation of leaf xylem embolism, thereby strengthening the relative contribution of the bark to total transpiration. Therefore, vulnerability segmentation should enhance the time from leaf $P_{\text {crit }}$ to stem $P_{\text {crit }}$.

In the last 20 years, the VSH has gained renewed interest and great efforts have been made to demonstrate the existence or the lack of vulnerability segmentation across species (Johnson et al. 2016; Hochberg et al. 2016; Charrier et al. 2016; Skelton et al. 2017, 2018; Rodriguez-Dominguez et al. 2018; Klepsch et al. 2018; Levionnois et al. 2020; Smith-Martin et al. 2020; Li et al. 2020). However, even if it is clear that vulnerability segmentation at the leaf-stem transition can be common, and is species dependant, the functional significance of vulnerability segmentation in the perspective of drought resistance remains unclear and poorly investigated. Recently, Blackman et al. (2019b) showed that leaf-stem vulnerability segmentation explains $t_{\text {crit }}$ for Eucalyptus species. Such approach needs to be replicated to identify to what extent we need to recognise vulnerability segmentation as an important drought resistance mechanism in most biomes and lineages across the world, which would enable better predictions of tree and vegetation dynamics under climate change (Martin-StPaul et al. 2017; Brodribb et al. 2020).

The strength of the effect of vulnerability segmentation on desiccation time can theoretically be affected by several factors. For instance, vulnerability segmentation implies that leaf xylem embolism reduces the total leaf evaporative surface. But the difference between leaf and bark area (or the leaf area-to-bark area ratio) at a given level (e.g. the shoot, the branch, the tree) can vary across species, potentially affecting the functional significance of vulnerability segmentation on desiccation time across species. Moreover, to our knowledge, a comparison between $g_{\min }$ and $g_{\text {bark }}$ has not been analysed yet. It can be hypothesised that the minimum conductance is different between leaf and bark, further affecting desiccation time after vulnerability segmentation across species. Finally, the ratio between the total water content and the evaporative surface is another parameter behind vulnerability segmentation, potentially varying across species and then affecting desiccation time. However, these parameters have never been investigated in the perspective of vulnerability segmentation controlling for desiccation time across species.

Here, we aim to test the theoretical effect of leaf-stem vulnerability segmentation on desiccation time of shoots across Neotropical rainforest canopy tree species. Rainforest species have previously been suggested to lack vulnerability segmentation (Zhu et al. 2016), but Levionnois et al. (2020) recently showed that vulnerability segmentation was common across nearly half of the tropical tree species they studied. Based on data from Levionnois et al. (2020), and by incorporating novel measurements, we calculated desiccation time at the shoot level, with a trait-based model taking or not vulnerability segmentation into account. We also added bark conductance and surface-area measurements to fully characterise the theoretical effect of vulnerability segmentation. We specifically addressed the following questions:

- Does leaf-stem vulnerability segmentation have a theoretical effect on desiccation time of tropical tree 
shoots? After answering this question, we also discuss future directions to improve estimations of desiccation time to better take into account vulnerability segmentation.

- What are the mechanisms (i.e. $P_{\text {crit,leaf }}-P_{\text {crit,stem }} ; g_{\min }-$ $\left.g_{\text {bark }} ; A_{\text {leaf }}-A_{\text {bark }}\right)$ allowing to expand shoot desiccation time through vulnerability segmentation?

\section{Materials and methods}

\subsection{Study site, species, and design}

The experiment was conducted in French Guiana at the Paracou experimental station (https://paracou.cirad.fr/ website; $5^{\circ} 16^{\prime} 26^{\prime \prime} \mathrm{N}, 52^{\circ} 55^{\prime} 26^{\prime \prime} \mathrm{W}$ ), which represents a lowland tropical rainforest (Gourlet-Fleury et al. 2004). The warm and wet tropical climate of French Guiana is highly seasonal due to the North-South movement of the Intertropical Convergence Zone. Mean $( \pm \mathrm{SE})$ annual air temperature is $25.7{ }^{\circ} \mathrm{C} \pm 0.1{ }^{\circ} \mathrm{C}$ and the mean annual precipitation is $3,102 \mathrm{~mm} \pm 70 \mathrm{~mm}$ (data between 2004 and 2014; Aguilos et al. 2019). There is a dry season lasting from mid-August to mid-November, during which rainfall is $<100 \mathrm{~mm} \mathrm{month}^{-1}$.

We sampled only dominant canopy trees, and only growing on terra firme. A total of 50 trees belonging to 18 species and 50 trees were sampled, with three trees per species for 14 species, and two trees per species for four species (Bocoa prouacensis, Iryanthera sagotiana, Moronobea coccinea, Qualea rosea). These 50 trees represent a subset of the sampling in Ziegler et al. (2019), for which stem embolism resistance was initially measured. The same dataset was used by Levionnois et al. (2020), who added data on leaf embolism resistance. Measurements of stem or leaf embolism resistance were particularly challenging for species for which data on only two individuals were available. Although several samples have been collected for a given species, only two vulnerability curves (VC) per species could be obtained (Ziegler et al. 2019; Levionnois et al. 2020). The studied species covered a broad phylogenetic diversity such that the main clades of the flowering plants were represented, i.e. magnoliids, rosids, and asterids. Branches were sampled by professional tree climbers.

We calculated desiccation time at the shoot level, with a shoot defined in the context of this study as an unbranched and leafy stem, with the largest possible number of leaves and with all nodes bearing a leaf. The traits necessary for calculating shoot desiccation time were measured as much as possible at the shoot level, except for stem embolism resistance and stem capacitance, which were measured further upstream, on older branch sections $(\sim 2 \mathrm{~cm}$ in diameter).

\subsection{Stem embolism resistance}

Stem embolism resistance was measured as the stem water potential inducing $50 \%$ and $88 \%$ loss of conductivity $\left(P_{50, \text { stem }}\right.$ and $P_{88 \text {,stem }}$, respectively; MPa; Table 1). Sample collection was held between January and July 2017, with one 3-m-long canopy branch sampled per tree. Only sun-exposed branches were sampled, except for the understory species Gustavia hexapetala. Vulnerability curves were measured with the flow-centrifugation technique using a Cavi1000 system (DGMeca, BIOGECO lab, Gradignan, France). A detailed description of the methods and the data for each species were provided and discussed by Ziegler et al. (2019).

\subsection{Leaf embolism resistance}

Leaf embolism resistance was measured as the leaf water potential inducing $50 \%$ and $88 \%$ loss of conductivity, respectively ( $\mathrm{P}_{50, \text { leaf }}$ and $\mathrm{P}_{88 \text {,leaf }}$ respectively; $\mathrm{MPa}$; Table 1$)$. The field sampling was held between November 2018 and March 2019, on the same trees that were sampled for the measurements of stem embolism resistance. We generally sampled three trees per sampling day, during the morning and before solar midday, in order to avoid too negative leaf water potentials and potential native leaf embolism. Only sun-exposed branches were sampled as much as possible. One 1-m-long canopy branch was sampled per tree, with $\sim 50$ leaves or leaflets for the monitoring of water potentials, as described below. A second small branch was also sampled for bark conductance and morphological measurements, as described below. To measure leaf xylem embolism resistance, we relied on the optical light transmission method (Brodribb et al., 2016a, 2016b; https://www.opensourceov. org). For details about the method and data for each species of this study, we refer the reader to Levionnois et al. (2020).

\subsection{Leaf pressure-volume curves}

Stomatal closure is generally measured from the stomatal response curve to leaf water potential based on stomatal conductance measurements. However, $\Psi_{\text {closure }}$ and leaf water potential at leaf turgor loss point $\left(\Psi_{\mathrm{tlp}} ; \mathrm{MPa}\right.$; Table 1) are strongly related (Brodribb et al. 2003; Rodriguez-Dominguez et al. 2016; Bartlett et al. 2016), leading to the possibility to use $\Psi_{\text {tlp }}$ as a surrogate of $\Psi_{\text {closure }}$ (Martin-StPaul et al. 2017). $\Psi_{\text {tlp }}$ was measured by pressure-volume analysis using the bench drying technique (Koide et al., 1989). Pressure-volume measurements were based on the measurement of one leaf per tree. Before the branch used for the measurement of leaf embolism resistance was removed from water and plastic bags, one fully hydrated and healthy leaf was sampled. At regular intervals, leaf water potential was measured with a Scholander pressure chamber (Model 
Table 1 List of traits, abbreviations, and formula when appropriate

\begin{tabular}{|c|c|c|c|}
\hline Abbreviation & Unit & Trait & Formula \\
\hline$t_{\text {crit }}$ & $\mathrm{h}$ & Shoot desiccation time & See materials and methods \\
\hline$P_{88 \text {,stem }}$ & $\mathrm{MPa}$ & Water potential at stem $88 \%$ loss of conductivity & \\
\hline$P_{88, \text { leaf }}$ & $\mathrm{MPa}$ & Water potential at leaf $88 \%$ loss of conductivity & \\
\hline$P_{50, \text { stem }}$ & $\mathrm{MPa}$ & Water potential at stem $50 \%$ loss of conductivity & \\
\hline$P_{50, \text { leaf }}$ & $\mathrm{MPa}$ & Water potential at leaf $50 \%$ loss of conductivity & \\
\hline$\Psi_{\text {tlp }}$ & $\mathrm{MPa}$ & Water potential at leaf turgor loss point & \\
\hline$A_{\text {leaf }}$ & $\mathrm{m}^{2}$ & Shoot leaf area & \\
\hline$A_{\text {bark }}$ & $\mathrm{m}^{2}$ & Stem bark area & \\
\hline$V_{\text {stem }}$ & $\mathrm{m}^{3}$ & Stem volume & \\
\hline$g_{\min }$ & $\mathrm{mmol} \mathrm{m}^{-2} \mathrm{~s}^{-1}$ & Leaf minimum conductance & \\
\hline$g_{\text {bark }}$ & $\mathrm{mmol} \mathrm{m} \mathrm{s}^{-1}$ & Bark conductance & \\
\hline$W_{\mathrm{ft}, \mathrm{stem}}$ & $\mathrm{mmol} \mathrm{m}^{-3} \mathrm{MPa}^{-1}$ & Estimated stem capacitance at full turgor & $W_{\mathrm{ft}, \mathrm{stem}}=-930.93 *$ wood density $+868.97^{\mathrm{a}}$ \\
\hline$W_{\text {tlp,leaf }}$ & $\mathrm{mmol} \mathrm{m}^{-3} \mathrm{MPa}^{-1}$ & Leaf capacitance after turgor loss point & \\
\hline SHSM & $\mathrm{MPa}$ & Stomatal-hydraulic safety margin & $\Psi_{\mathrm{tlp}}-P_{88, \mathrm{stem}}$ or $\Psi_{\mathrm{tlp}}-P_{50, \text { stem }}$ \\
\hline$g_{\text {min }} * 2 A_{\text {leaf }}$ b & $\mathrm{mmol} \mathrm{s}^{-1}$ & Leaf minimum transpiration rate & \\
\hline$g_{\text {bark }} * A_{\text {bark }}$ & $\mathrm{mmol} \mathrm{s}^{-1}$ & Bark transpiration rate & \\
\hline$C_{\text {shoot }} A_{\text {leaf +bark }}^{-1 \mathrm{~b}}$ & $\mathrm{mmol} \mathrm{MPa}^{-1} \mathrm{~m}^{-2}$ & Shoot capacity to total evaporative surface & $\left(W_{\text {ft,stem }} V_{\text {stem }}+W_{\text {tlp,leaf }} A_{\text {leaf }}\right) /\left(2 A_{\text {leaf }}+A_{\text {bark }}\right)^{\mathrm{b}}$ \\
\hline$C_{\text {stem }} A_{\text {bark }}^{-1}$ & $\mathrm{mmol} \mathrm{MPa}{ }^{-1} \mathrm{~m}^{-2}$ & Stem capacity to bark surface & $W_{\mathrm{ft}, \mathrm{stem}} V_{\mathrm{stem}} / A_{\text {bark }}$ \\
\hline
\end{tabular}

${ }^{\text {a }}$ Santiago et al. (2018)

${ }^{\mathrm{b}} A_{\text {leaf }}$ is multiplied by 2 as transpiration occurs at both abaxial and adaxial leaf sides

600 , PMS), directly followed by the measurement of leaf mass with a precision balance (AB 204-S, Mettler Toledo). The different water potential and mass measurements were made to cover the range from 0.00 to $-3.00 \mathrm{MPa}$ (or more if necessary as the dynamic of water potential drop is generally clearly noticeable during measurement), with ca. $0.30 \mathrm{MPa}$ intervals. Then, the leaf was scanned to measure leaf area, and dried for 3 days at $70{ }^{\circ} \mathrm{C}$ to measure leaf dry mass $\Psi_{\text {tlp }}$ being the leaf water potential at the phase transition (Koide et al. 1989). The pressure-volume curve was also used to derive leaf capacitance after turgor loss $W_{\text {tlp,leaf }}(\mathrm{mmol}$ $\mathrm{m}^{-2} \mathrm{MPa}^{-1}$; Table 1), since the plant water stock used for the calculation of $t_{\text {crit }}$ is the water available in plant tissues after stomatal closure. $W_{\text {tlp,leaf }}$ was calculated as the slope of the loss of leaf water mass according to leaf water potential for water potentials below $\Psi_{\text {tlp }}$, and divided by the leaf area.

\subsection{Stem capacitance}

Wood capacitance is negatively related to wood density (Scholz et al. 2011; Mcculloh et al. 2014; Jupa et al. 2016; Santiago et al. 2018). Santiago et al. (2018) recently measured branch wood capacitance at full-turgor $\left(W_{\mathrm{ft}, \mathrm{stem}} ; \mathrm{kg}\right.$ $\mathrm{m}^{-3} \mathrm{MPa}^{-1}$ ) across 14 tropical rainforest canopy tree species at the same site as this present study in Paracou, French Guiana. Santiago et al. (2018) found a linear relationship $\left(R^{2}=0.59\right)$ between $W_{\mathrm{ft}, \text { stem }}$ and branch wood density (WD, $\mathrm{g} \mathrm{cm}^{-3}$; Table 1), such as: $W_{\mathrm{ft} \text { stem }}=-930.93 * \mathrm{WD}+868.97$.
We used the estimation of wood capacitance as a proxy for whole stem capacitance. We are aware that the different stem tissues (pith, xylem, phloem, cortex) can exhibit different capacitances, but we assume capacitances between stem tissues to be coordinated across species. During field work for the measurements of stem embolism resistance, we sampled short stem segments $(\sim 1.5 \mathrm{~cm}$ in length; $\sim 1 \mathrm{~cm}$ in diameter) for WD measurements. One wood sample was sampled per branch, on the distal extremity of the sample used for the Cavi1000 measurement. The fresh volume of the sample was calculated using an inverse Archimedes principle and a precision balance (CP224S, Sartorius), as the difference between fresh mass and immersed mass of the sample. Dry mass was derived after drying at $103{ }^{\circ} \mathrm{C}$ for 3 days. WD was calculated as the ratio between dry mass and fresh volume. In this present study, WD varied from 0.49 to 0.85 , whereas WD in the study of Santiago et al. (2018) varied from 0.33 to 0.80 .

\subsection{Leaf and bark minimum conductance}

Leaf minimum conductance $g_{\text {min }}\left(\mathrm{mmol} \mathrm{m} \mathrm{mPa}^{-1}\right.$; Table 1) was measured between July and November 2017, with the method of weight loss of detached leaves (Blackman et al. 2019b; Duursma et al. 2019). During field work for the measurements of stem embolism resistance, while sampling the branches, strings were tied to sunlit shoots to facilitate later canopy sampling without climbing. $g_{\min }$ was 
measured on one leaf per tree. Immediately after leaf sampling, leaves were placed in small sealed plastic bags with wet paper towels to avoid dehydration. At the laboratory, the entire leaf surface was gently padded dry with dry paper towels. The cut petiole was sealed with nail polish such that the total leaf transpiration was only mediated by the lamina. Leaves were placed $1 \mathrm{~m}$ above air fans and let to dehydrate in a closed air-conditioned room. Air temperature and relative humidity were maintained at ca. $25^{\circ} \mathrm{C}$ and ca. $50 \%$, respectively. At regular intervals, leaf mass was recorded with a precision balance (AB 204-S, Mettler Toledo). Time, air temperature, and relative air humidity were noted for each measurement. $g_{\min }$ was calculated as the slope of decreasing leaf mass according to time, in conjunction with VPD-calculated from the known air temperature and relative humidity and divided by the doubled leaf area. Particular attention was paid to the kinetics of water loss, by estimating $g_{\min }$ only during the solely linear phase of leaf water mass decrease with time after stomata had closed.

The bark conductance $g_{\text {bark }}\left(\mathrm{mmol} \mathrm{m}{ }^{-2} \mathrm{MPa}^{-1}\right.$; Table 1$)$ was measured during the measurement of leaf embolism resistance, for which a second small branch was sampled. From this branch, three $20-\mathrm{cm}$-long and $\sim 1$-cm-diameter stem segments were sampled, by paying attention to have linear and unbranched stem segments. Then, the segments were placed in small sealed plastic bags with wet paper towels to avoid dehydration and eventual bark shrinkage. At the laboratory, the entire bark surface was dried with paper towels. The two extremities of each stem segment were sealed with melted wax such that the total stem segment transpiration was only mediated by the bark. $g_{\text {bark }}$ was measured exactly in the same manner as described for leaves, but the slope of the decreasing water mass of the stem segment over time was divided by the bark surface area. Particular attention was paid to the kinetics of water loss only during the solely linear phase of leaf water mass decrease with time. This also allowed to avoid biases due to the potential release of water that would be just recently absorbed by the bark. The bark surface area was measured by considering the stem segment as a cylinder, based on measurements of stem length and diameter.

\subsection{Morphological parameters}

Shoot leaf area $\left(A_{\text {leaf }} ; \mathrm{m}^{2}\right)$ and shoot bark area $\left(A_{\text {bark }} ; \mathrm{m}^{2}\right)$ were quantified during leaf embolism resistance measurements, with a second small branch used for bark conductance measurements only. On this branch, a shoot was sampled, defined as an unbranched stem supporting as many leaves as possible, but with no missing or damaged leaves between the youngest and the oldest leaf. Once sampled from the tree, shoots were placed in sealed plastic bags with wet paper towels to avoid dehydration. At the laboratory, all the surfaces were dried with paper towels. All the leaves were cut and scanned to measure total shoot leaf area (Table 1). The shoot bark area was measured by considering the shoot stem as a cylinder, from length and diameter measurements (Table 1). The stem volume $\left(V_{\text {stem }} ; \mathrm{m}^{3}\right)$ was calculated as a cylinder.

\subsection{The desiccation time model}

To test the effect of vulnerability segmentation on $t_{\text {crit }}$, we calculated $t_{\text {crit }}$ for species exhibiting a positive vulnerability segmentation (i.e. $P_{88 \text {,leaf }}>P_{88 \text {,stem }}$; Levionnois et al., 2020), representing 12 species. Then, we calculated for the same species a theoretical $t_{\text {crit }}$ with no segmentation, such as $P_{88 \text {, leaf }}=P_{88, \text { stem }}$. To take into account the vulnerability segmentation in our calculation of $t_{\text {crit }}$, we used the framework of Blackman et al. (2016) and refined the model. We added two successive desiccation times: (i) leaf desiccation time, from stomatal closure to leaf xylem hydraulic failure, and (ii) stem desiccation time, from leaf xylem to stem xylem hydraulic failure. The model assumes that during phase (i), shoot transpiration is driven by both $g_{\text {min }}$ and $g_{\text {bark }}$; but that during phase (ii), shoot transpiration is driven by $g_{\text {bark }}$ only. Contrary to Blackman et al. (2016) we also added the effect of the leaf capacitance after leaf turgor loss point, but before leaf xylem hydraulic failure. We used $P_{88, \text { leaf }}$ and $P_{88 \text {,stem }}$ as parameters for critical leaf and stem hydraulic failure, respectively (Blackman et al. 2016), as $P_{88 \text {,stem }}$ has been shown to trigger plant mortality for angiosperm species (Urli et al. 2013). Therefore, $t_{\text {crit_seg }}$ for species exhibiting a positive vulnerability segmentation was calculated as:

$$
\begin{aligned}
& t_{\text {crit_seg }}= \frac{\left(\Psi_{\text {tlp }}-P_{88, \text { leaf }}\right) *\left(W_{f t, \text { stem }} V_{\text {stem }}+W_{t l p, \text { leaf }} A_{\text {leaf }}\right)}{\left(2 A_{\text {leaf }} g_{\text {min }}+A_{\text {bark }} g_{\text {bark }}\right) * 3600 * V P D} \\
&+\frac{\left(P_{88, \text { leaf }}-P_{88, \text { stem }}\right) * W_{f t, \text { stem }} V_{\text {stem }}}{A_{\text {bark }} g_{\text {bark }} * 3600 * V P D}
\end{aligned}
$$

where $\Psi_{\text {tlp }}$ is the water potential (MPa) at turgor loss point used as a surrogate of stomatal closure; $P_{88 \text {,leaf }}$ is the leaf water potential (MPa) at $88 \%$ loss of leaf xylem conductivity; $P_{88 \text { stem }}$ is the water potential (MPa) at $88 \%$ loss of stem xylem conductivity; $W_{\mathrm{ft}, \mathrm{stem}}$ is the stem capacitance $\left(\mathrm{kg} \mathrm{m}^{-3} \mathrm{MPa}^{-1}\right.$, but divided by the water molar mass of $\left.18.015 \times 10^{-6} \mathrm{~kg} \mathrm{mmol}^{-1}\right)$ at full turgor; $W_{\text {tlp,leaf }}$ is the leaf capacitance $\left(\mathrm{mmol} \mathrm{m}^{-2} \mathrm{MPa}^{-1}\right)$ after leaf turgor loss point; $V_{\text {stem }}$ is the stem volume $\left(\mathrm{m}^{3}\right) ; A_{\text {leaf }}$ is the shoot leaf area $\left(\mathrm{m}^{2}\right) ; g_{\min }$ is the leaf minimum conductance (mmol $\left.\mathrm{m}^{-2} \mathrm{~s}^{-1}\right) ; g_{\text {bark }}$ is the bark conductance $\left(\mathrm{mmol} \mathrm{m}^{-2} \mathrm{~s}^{-1}\right)$; and $V P D$ is the vapour pressure deficit $\left(\mathrm{mol} \mathrm{mol}^{-1}\right)$. The factor 3,600 converts seconds in hours. Then, for species exhibiting a positive vulnerability segmentation, we artificially 
cancelled the segmentation by calculating a $t_{\text {crit_noseg, }}$, with $P_{88, \text { leaf }}=P_{88, \text { stem }}$, and therefore:

$t_{\text {crit_noseg }}=\frac{\left(\Psi_{\text {tlp }}-P_{88, \text { stem }}\right) *\left(W_{f t \text {,stem }} V_{\text {stem }}+W_{\text {tpp,leaf }} A_{\text {leaf }}\right)}{\left(2 A_{\text {leaf }} g_{\text {min }}+A_{\text {bark }} g_{\text {bark }}\right) * 3600 * V P D}$

All the parameters of the models and per species are presented in the Table 2. To better characterise how vulnerability segmentation expands $t_{\text {crit }}$, we calculated additional traits at the shoot and stem levels by combining couples of aforementioned traits (Table 1) that we compared across shoot and stem levels. We calculated leaf minimum transpiration rate $\left(\mathrm{g}_{\min } * 2 A_{\text {leaf }} ;\right.$ mmol s$\left.{ }^{-1}\right)$ as the product of $g_{\text {min }}$ and shoot leaf area multiplied by 2 (because transpiration occurs at both abaxial and adaxial sides). We calculated bark transpiration rate $\left(g_{\text {bark }} * A_{\text {bark }} ; \mathrm{mmol} \mathrm{s}^{-1}\right)$ at the shoot level. For the $A_{\text {bark }}$ considered, we come back to our definition of the leafy shoot, as a single unbranched stem supporting the most leaves, with no missing or damaged leaves between the youngest and the oldest leaf. Then, $A_{\text {bark }}$ was directly related to the number of nodes and leaves that constitute the leafy shoot. We calculated shoot capacity to total evaporative surface $\left(C_{\text {shoot }} A_{\text {leaf }+ \text { bark }}{ }^{-1} ; \mathrm{mmol} \mathrm{MPa}^{-1} \mathrm{~m}^{-2}\right)$, by multiplying $A_{\text {leaf }}$ by 2 . We calculated stem capacity to bark surface $\left(C_{\text {stem }}\right.$ $A_{\text {bark }}{ }^{-1} ; \mathrm{mmol} \mathrm{MPa}^{-1} \mathrm{~m}^{-2}$ ). Capacity to evaporative surface translates the available stored water which will evaporate during dehydration as a function of total evaporative surface, with a higher capacity to evaporative surface amplifying the positive effect of stored water on drought resistance.

\subsection{Statistical analyses}

All statistical analyses were performed in R (R Core Team 2018). Data were tested for normality (Shapiro-Wilk test; $\alpha=0.05$ ). For correlations between traits, we used Pearson or Spearman correlation analyses depending on the normality. Comparison tests were conducted with Student's, Welch's, or Mann-Whitney-Wilcoxon's test, depending on the parameters of the samples (sample size, normality of distribution, variance).

To test for the effect of a given trait on $t_{\text {crit }}$, it would be appropriate to apply a variance decomposition, which requires a multiple linear model based on the sum of explanatory variables. However, the $t_{\text {crit }}$ model is rather based on products. Switching from a product-based to a sum-based model is feasible with a log transformation. But in this case, this rather leads to a more complex model where the application of variance decomposition would lose its relevance. Therefore, as $R^{2}$ in bivariate relationships conveys information on explained variance, we calculated $R^{2}$ for relationships between $t_{\text {crit }}$ (response variable) and a given constitutive trait of the model (predictive variable). This was realised for all traits constitutive of the $t_{\text {crit }}$ model and ordered the relationships according to $R^{2}$. Then, we assumed that traits with higher $R^{2}$ have the strongest relative contribution to $t_{\text {crit }}$.

\section{Results}

For the 12 species exhibiting a positive vulnerability segmentation $\left(P_{88, \text { leaf }}>P_{88 \text {,stem }}\right)$, there was a significant difference between $t_{\text {crit_seg }}$ and $t_{\text {crit_noseg }}$ (Fig. 1), with a mean of $235.9 \pm 71.3 \mathrm{~h}( \pm \mathrm{SE})$ and $9.0 \pm 2.1 \mathrm{~h}$, respectively.

When considering all species, including species with both positive $\left(P_{88 \text {, leaf }}>P_{88 \text {,stem }}\right)$ and negative $\left(P_{88, \text { leaf }}<P_{88 \text {,stem }}\right)$ vulnerability segmentation, $t_{\text {crit }}$ was positively related to the degree of $P_{88^{-}}$-segmentation (Fig. 2a) as well as the degree of $P_{50}$-segmentation (Fig. 2b), such that larger positive segmentation degree was associated with longer shoot desiccation time. $t_{\text {crit }} \times$ VPD was also positively related to the stomatal-hydraulic safety margin (SHSM; MPa) when considering both $P_{88, \text { stem }}$ (Fig. 2c) and $P_{50 \text {,stem }}$ (Fig. 2d), such that larger safety margin was associated with longer shoot desiccation time.

From all the constitutive traits of the $t_{\text {crit }}$ model, $P_{88}$-segmentation and SHSM were the traits with the highest $R^{2}$, both when considering species altogether or when considering only species exhibiting a positive vulnerability segmentation $\left(P_{88, \text { leaf }}>P_{88, \text { stem }}\right)$ (Table 3$)$. This suggests that $P_{88}$-segmentation and SHSM had the highest relative contribution to $t_{\text {crit }}$.

For the 12 species exhibiting a positive vulnerability segmentation $\left(P_{88, \text { leaf }}>P_{88, \text { stem }}\right)$, there was a significant difference between $P_{88, \text { leaf }}$ and $P_{88, \text { stem }}$ across species (Fig. 3a), with a mean of $-4.10 \pm 0.29 \mathrm{MPa}$ and $-6.08 \pm 0.62 \mathrm{MPa}$, respectively. There was no significant difference between $g_{\text {min }}$ and $g_{\text {bark }}$ (Fig. 3b), with a mean of $5.529 \pm 0.993 \mathrm{mmol} \mathrm{m}^{-2} \mathrm{~s}^{-1}$ and $4.285 \pm 0.386 \mathrm{mmol} \mathrm{m}^{-2} \mathrm{~s}^{-1}$, respectively. There was a significant difference in evaporative surfaces, between $2 * A_{\text {leaf }}$ and $A_{\text {bark }}$ (Fig. $3 \mathrm{c}$ ), with a mean of $780.0 \pm 171.6 \mathrm{~cm}^{2}$ and $13.40 \pm 1.91 \mathrm{~cm}^{2}$, respectively. A significant difference was also found between minimum leaf minimum transpiration $\left(g_{\text {min }} * 2 A_{\text {leaf }}\right)$ and bark transpiration $\left(g_{\text {bark }} * A_{\text {bark }}\right.$; Fig. $\left.3 \mathrm{~d}\right)$, with a mean of $0.513 \pm 0.251 \mathrm{mmol} \mathrm{s}^{-1}$ and $0.006 \pm 0.001 \mathrm{mmol} \mathrm{s}^{-1}$, respectively. There was also a significant difference between shoot capacity per evaporative surface $\left(C_{\text {shoot }}\right.$ $\left.A_{\text {leaf +bark }}{ }^{-1}\right)$ and stem capacity per bark area $\left(C_{\text {stem }} A_{\text {bark }}{ }^{-1}\right.$; Fig. 3e), with a mean of $640.8 \pm 78.1 \mathrm{mmol} \mathrm{MPa}^{-1} \mathrm{~m}^{-2}$ and $15.226 \pm 2.406 \mathrm{mmol} \mathrm{MPa}^{-1} \mathrm{~m}^{-2}$, respectively, such that the total capacity per evaporative surface was higher following leaf embolism.

For the 12 species exhibiting a positive vulnerability segmentation $\left(P_{88 \text {,leaf }}>P_{88 \text {,stem }}\right), t_{\text {crit_seg }}$ was not related to the difference between $g_{\min }$ and $g_{\text {bark }}$ (Fig. $4 \mathrm{a}$ ), nor to the 
Table 2 List of the tropical rainforest tree species studied with reference to the traits that were used to estimate the desiccation time of shoots

\begin{tabular}{|c|c|c|c|c|c|c|}
\hline Species & Family & $\Psi_{t \mathrm{p}}(\mathrm{MPa})$ & $P_{88, \text { stem }}(\mathrm{MPa})$ & $P_{88, \text { leaf }}(\mathrm{MPa})$ & $\underset{\left.\mathrm{m}^{-2} \mathrm{~s}^{-1}\right)}{g_{\min }(\mathrm{mmol}}$ & $g_{\text {bark }}\left(\mathrm{mmol} \mathrm{m}^{-2} \mathrm{~s}^{-1}\right)$ \\
\hline Protium opacum & Burseraceae & $-1.54 \pm 0.11$ & $-3.13 \pm 0.17$ & $-3.26 \pm 0.80$ & $3.235 \pm 0.178$ & $7.318 \pm 0.989$ \\
\hline $\begin{array}{l}\text { Licania membrana- } \\
\quad \text { cea }\end{array}$ & Chrysobalanaceae & $-2.30 \pm 0.02$ & $-5.26 \pm 0.59$ & $-4.26 \pm 0.89$ & $8.199 \pm 2.281$ & $5.109 \pm 0.583$ \\
\hline Symphonia sp1 & Clusiaceae & $-1.48 \pm 0.11$ & $-2.58 \pm 0.07$ & $-2.55 \pm 0.10$ & $5.460 \pm 0.898$ & $5.229 \pm 0.997$ \\
\hline Bocoa prouacensis & Fabaceae & $-2.92 \pm 0.24$ & $-5.17 \pm 0.32$ & $-5.43 \pm 0.26$ & $4.809 \pm 1.721$ & $6.464 \pm 0.594$ \\
\hline $\begin{array}{l}\text { Dicorynia guian- } \\
\text { ensis }\end{array}$ & Fabaceae & $-1.33 \pm 0.19$ & $-3.23 \pm 0.03$ & $-4.33 \pm 1.08$ & $6.503 \pm 1.081$ & $4.220 \pm 0.273$ \\
\hline Eperua falcata & Fabaceae & $-1.35 \pm 0.22$ & $-4.70 \pm 0.77$ & $-4.27 \pm 0.26$ & $3.008 \pm 0.787$ & $3.085 \pm 0.554$ \\
\hline Eperua grandiflora & Fabaceae & $-1.64 \pm 0.08$ & $-6.91 \pm 0.27$ & $-4.71 \pm 0.72$ & $3.235 \pm 0.594$ & $3.143 \pm 0.170$ \\
\hline Tachigali melinonii & Fabaceae & $-2.00 \pm 0.07$ & $-5.50 \pm 0.40$ & $-4.43 \pm 0.11$ & $5.805 \pm 0.493$ & $3.431 \pm 0.493$ \\
\hline Goupia glabra & Goupiaceae & $-1.77 \pm 0.14$ & $-6.78 \pm 0.19$ & $-3.86 \pm 0.45$ & $4.826 \pm 1.032$ & $5.022 \pm 0.183$ \\
\hline $\begin{array}{l}\text { Eschweilera sago- } \\
\text { tiana }\end{array}$ & Lecythidaceae & $-1.38 \pm 0.18$ & $-3.17 \pm 0.29$ & $-3.06 \pm 0.75$ & $1.877 \pm 0.564$ & $3.348 \pm 0.211$ \\
\hline Gustavia hexapetala & Lecythidaceae & $-1.60 \pm 0.24$ & $-8.49 \pm 0.36$ & $-5.52 \pm 0.80$ & $1.426 \pm 0.498$ & $3.915 \pm 0.931$ \\
\hline Lecythis poiteauii & Lecythidaceae & $-1.72 \pm 0.07$ & $-2.50 \pm 0.19$ & $-4.10 \pm 1.34$ & $3.123 \pm 0.387$ & $3.251 \pm 0.287$ \\
\hline Virola michelii & Myristicaceae & $-1.67 \pm 0.21$ & $-6.47 \pm 0.32$ & $-3.28 \pm 0.59$ & $7.189 \pm 1.321$ & $4.011 \pm 0.888$ \\
\hline $\begin{array}{l}\text { Chaetocarpus } \\
\text { schomburgkianus }\end{array}$ & Peraceae & $-1.98 \pm 0.07$ & $-3.27 \pm 0.47$ & $-2.72 \pm 0.61$ & $8.701 \pm 0.972$ & $7.195 \pm 2.604$ \\
\hline $\begin{array}{l}\text { Chrysophyllum } \\
\text { sanguinolentum }\end{array}$ & Sapotaceae & $-1.89 \pm 0.09$ & $-4.46 \pm 0.11$ & $-2.55 \pm 0.97$ & $13.53 \pm 5.707$ & $6.248 \pm 0.520$ \\
\hline $\begin{array}{l}\text { Manilkara biden- } \\
\quad \text { data }\end{array}$ & Sapotaceae & $-2.47 \pm 0.34$ & $-10.45 \pm 0.92$ & $-5.30 \pm 1.09$ & $3.669 \pm 1.334$ & $3.156 \pm 0.584$ \\
\hline Pradosia cochlearia & Sapotaceae & $-1.97 \pm 0.09$ & $-7.50 \pm 0.12$ & $-5.24 \pm 0.50$ & $4.881 \pm 2.541$ & $3.755 \pm 0.620$ \\
\hline Qualea rosea & Vochysiaceae & $-2.20 \pm 0.27$ & $-2.72 \pm 0.04$ & $-3.23 \pm 0.45$ & $6.399 \pm 3.003$ & $4.677 \pm 0.349$ \\
\hline Species & Family & $\begin{array}{l}W_{\mathrm{ft}, \mathrm{stem}}(\mathrm{kg} \\
\left.\mathrm{m}^{-3} \mathrm{MPa}^{-1}\right)^{*}\end{array}$ & $\begin{array}{l}W_{\text {tlp, leaf }}(\mathrm{g} \\
\left.\mathrm{m}^{-2} \mathrm{MPa}^{-1}\right)^{*}\end{array}$ & $A_{\text {leaf }}\left(\mathrm{cm}^{2}\right)^{*}$ & $A_{\text {bark }}\left(\mathrm{cm}^{2}\right)^{*}$ & $V_{\text {stem }}\left(\mathrm{cm}^{-3}\right)^{*}$ \\
\hline Protium opacum & Burseraceae & $321.3 \pm 30.7$ & $0.263 \pm 0.011$ & 1861.9 & 28.4 & 5.495 \\
\hline $\begin{array}{l}\text { Licania membrana- } \\
\qquad \text { cea }\end{array}$ & Chrysobalanaceae & $184.3 \pm 30.4$ & $1.808 \pm 0.340$ & 163.2 & 9.4 & 0.661 \\
\hline Symphonia sp1 & Clusiaceae & $244.7 \pm 33.8$ & $1.698 \pm 0.351$ & 116.1 & 6.0 & 0.408 \\
\hline Bocoa prouacensis & Fabaceae & $107.3 \pm 21.3$ & $0.682 \pm 0.242$ & 182.9 & 10.6 & 0.716 \\
\hline $\begin{array}{l}\text { Dicorynia guian- } \\
\text { ensis }\end{array}$ & Fabaceae & $332.8 \pm 33.9$ & $2.209 \pm 0.151$ & 1179.2 & 24.4 & 4.019 \\
\hline Eperua falcata & Fabaceae & $388.2 \pm 21.0$ & $1.150 \pm 0.246$ & 401.2 & 19.8 & 1.763 \\
\hline Eperua grandiflora & Fabaceae & $222.1 \pm 30.1$ & $1.437 \pm 0.243$ & 350.8 & 10.9 & 0.950 \\
\hline Tachigali melinonii & Fabaceae & $115.9 \pm 25.9$ & $1.841 \pm 0.750$ & 376.7 & 5.2 & 0.493 \\
\hline Goupia glabra & Goupiaceae & $296.2 \pm 11.4$ & $1.311 \pm 0.154$ & 205.1 & 19.7 & 1.286 \\
\hline $\begin{array}{l}\text { Eschweilera sago- } \\
\quad \text { tiana }\end{array}$ & Lecythidaceae & $216.1 \pm 11.9$ & $1.890 \pm 0.667$ & 278.2 & 12.3 & 1.209 \\
\hline Gustavia hexapetala & Lecythidaceae & $317.3 \pm 1.5$ & $2.049 \pm 0.699$ & 511.3 & 16.9 & 1.767 \\
\hline Lecythis poiteauii & Lecythidaceae & $208.3 \pm 32.7$ & $2.070 \pm 0.257$ & 340.6 & 18.4 & 1.732 \\
\hline Virola michelii & Myristicaceae & $302.8 \pm 37.0$ & $0.703 \pm 0.285$ & 265.9 & 11.2 & 1.179 \\
\hline $\begin{array}{l}\text { Chaetocarpus } \\
\text { schomburgkianus }\end{array}$ & Peraceae & $287.0 \pm 14.6$ & $2.572 \pm 0.199$ & 199.4 & 12.1 & 0.962 \\
\hline $\begin{array}{l}\text { Chrysophyllum } \\
\text { sanguinolentum }\end{array}$ & Sapotaceae & $328.0 \pm 35.5$ & $2.220 \pm 0.685$ & 1201.2 & 24.9 & 5.114 \\
\hline $\begin{array}{l}\text { Manilkara biden- } \\
\quad \text { data }\end{array}$ & Sapotaceae & $189.5 \pm 3.1$ & $1.700 \pm 0.199$ & 634.1 & 17.1 & 3.165 \\
\hline Pradosia cochlearia & Sapotaceae & $319.5 \pm 21.1$ & $1.815 \pm 0.692$ & 92.9 & 1.3 & 0.081 \\
\hline Qualea rosea & Vochysiaceae & $340.2 \pm 43.1$ & $3.219 \pm 1.631$ & 151.4 & 8.1 & 0.565 \\
\hline
\end{tabular}

Values are means $( \pm \mathrm{SE})$. All acronyms are listed in Table 1 


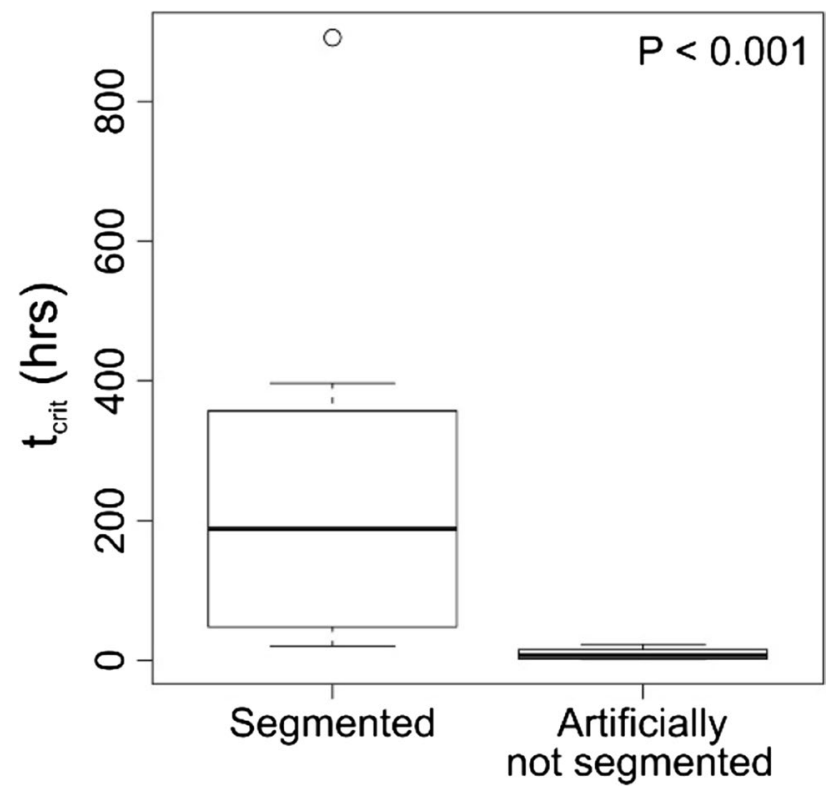

Fig. 1 Comparison for shoot desiccation time between the 12 positively segmented species $\left(P_{88 \text {,leaf }}>P_{88 \text {,stem }}\right)$ and the same species but artificially not segmented $\left(P_{88 \text {,leaf }}\right.$ is set as same value as $P_{88, \text { stem }}$ for each species). All abbreviations are presented in Table 1

difference between $2 A_{\text {leaf }}$ and $A_{\text {bark }}$ (Fig. 4b), nor to the difference between $g_{\min } * 2 A_{\text {leaf }}$ and $g_{\text {bark }} * A_{\text {bark }}$ (Fig. $4 \mathrm{c}$ ). $t_{\text {crit_seg }}$ was also not related to the difference between $C_{\text {shoot }}$ $A_{\text {leaftbark }}^{-1}$ and $C_{\text {stem }} A_{\text {bark }}^{-1}$ (Fig. $4 \mathrm{~d}$ ), even if a tendency exists at $P<0.1$.

\section{Discussion}

Our study demonstrates that leaf-stem vulnerability segmentation theoretically enhances shoot desiccation time, supporting that vulnerability segmentation is an efficient drought resistance mechanism in tropical rainforest tree species. The effect of vulnerability segmentation on $t_{\text {crit }}$ is mainly due to the difference in leaf vs. bark area at the shoot level, but not to any difference in area-based leaf vs. bark conductance. The results are based on theoretical estimations and the model assumes that no water flows from stem to leaf xylem after embolism has occurred in leaf xylem. Further empirical tests of this assumption are needed, but we argue that not incorporating vulnerability segmentation can result in a considerable underestimation of drought resistance.

\subsection{Leaf-stem vulnerability segmentation is a drought resistance mechanism}

Not accounting for vulnerability segmentation into our desiccation time model for species with a positive vulnerability segmentation $\left(P_{88, \text { leaf }}>P_{88, \text { stem }}\right)$ dramatically underestimated shoot desiccation time, which lost one order of magnitude, shifting from $235.9 \pm 71.3 \mathrm{~h}$ to $9.0 \pm 2.1$ h (Fig. 1). Moreover, the segmentation degree was the strongest predictor of $t_{\text {crit }}$ (Fig. 2a; Table 3). This finding highlights that leaf-stem vulnerability segmentation enhances - at least theoretically-shoot desiccation time, and is potentially a strong determinant of drought resistance at the leafy shoot level. This finding is in agreement with Blackman et al. (2019b), who found a relationship between the leaf-stem segmentation degree and observed $t_{\text {crit }}$ across eight Eucalyptus species in a controlled experiment. Furthermore, the degree of vulnerability segmentation seems to be as strong as the stomatal-hydraulic safety margin in determining $t_{\text {crit }}$ (SHSM; $\Psi_{\text {tlp }}-P_{\text {crit,stem }}$; Table 3$)$ in the context of the present study, bearing in mind that $\mathrm{P}_{\text {crit,stem }}$ can vary across species ( $\mathrm{Li}$ et al. 2016). This finding is also in agreement with Blackman et al. (2019b), who reported a higher coefficient of determination for $P_{50 \text {, leaf }}-P_{50 \text {,stem }}$ than SHSM, when predicting their observed $t_{\text {crit }}$. SHSM is an important drought resistance parameter, as it defines the complete sequence of drought stress, from stomatal closure to plant death, reflecting the water potential drop, the plant is able to sustain before die-back is likely. SHSM has already been shown to directly determine desiccation time in other studies, whether based on the integrative SurEau model (Martin-StPaul et al. 2017), or based on observations of desiccation time in controlled conditions (Blackman et al. 2019a). All these elements suggest vulnerability segmentation to be a drought resistance mechanism comparable in effectiveness to SHSM.

Consequently, future trait-based assessment of plant drought resistance should incorporate measurements of both $P_{50 \text {, leaf }}$ and $P_{50 \text {,stem }}$. Positive leaf-stem vulnerability segmentation is species dependant and common (Johnson et al. 2016; Hochberg et al. 2016; Charrier et al. 2016; Skelton et al. 2017, 2018; Rodriguez-Dominguez et al. 2018; Klepsch et al. 2018; Levionnois et al. 2020; SmithMartin et al. 2020; Li et al. 2020). Then, omitting $P_{50 \text {,leaf }}$ and assuming no vulnerability segmentation for each species can lead to a strong underestimation of plant drought resistance. Such underestimation can be an issue if hydraulic trait data are used in vegetation prediction models (Brodribb et al. 2020). However, in a long-term perspective, more data are needed to fully characterise vulnerability segmentation, desiccation time (measured or estimated), and drought resistance together. For instance, the way we consider drought resistance is a maximisation of survival during one particular water shortage, such as an exceptional long dry season. However, maximising of desiccation time through vulnerability segmentation comes at the cost of the functional crown, and carbon uptake. 
Fig. 2 Relationships between shoot desiccation time and vulnerability segmentation for all species. a Shoot desiccation time according to $P_{88}$-segmentation $\left(P_{88 \text {, leaf }}-P_{88 \text {,stem }}\right)$. b Shoot desiccation time according to $\mathrm{P}_{50}$-segmentation $\left(P_{50 \text {, leaf }}-\right.$ $\left.P_{50 \text {,stem }}\right)$. c Shoot desiccation time according to the stomatalhydraulic safety margin $\left(\Psi_{\text {tlp }}\right.$ $\left.-P_{88, \text { stem }}\right)$. d Shoot desiccation time according to the stomatalhydraulic safety margin $\left(\Psi_{\mathrm{tlp}}\right.$ $\left.-P_{50 \text {,stem }}\right)$. All abbreviations are presented in Table 1
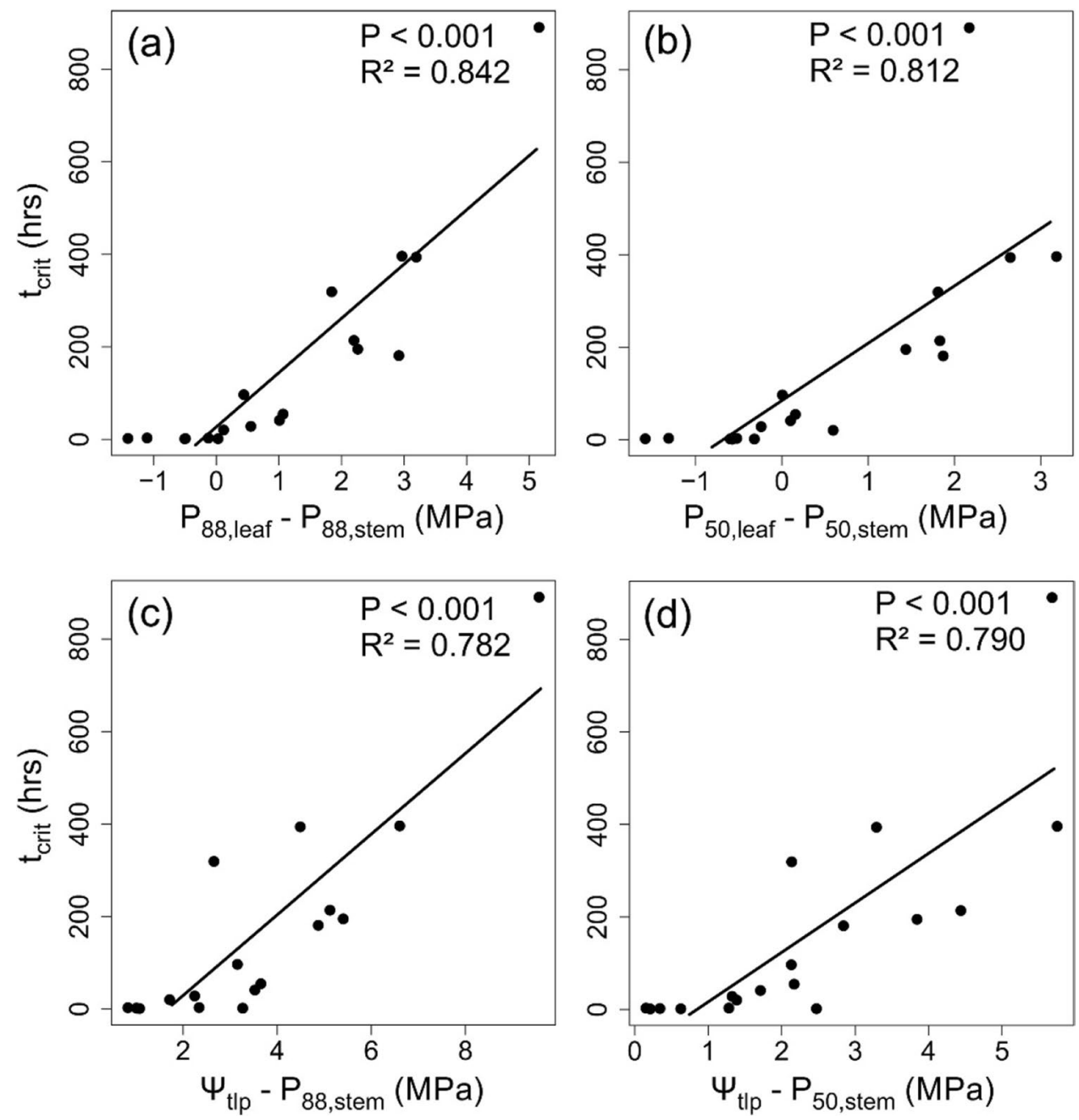

Repeatedly relying on vulnerability segmentation as a consequence of exceptional drought events could deplete carbon reserves, and finally impede growth. Overall, the resilience of trees and forests under repetitive periods of drought stress is largely unknown (DeSoto et al. 2020).

\subsection{Improving desiccation time estimations}

Future directions should also alleviate the assumptions on which the model is based. First, our model assumes that following leaf xylem embolism, there is no longer water flow from the stem to the leaf. This assumption directly and simply defines the abrupt loss of total evaporative surface following leaf embolism, shifting from shoot leaf area plus bark area, to bark area alone. This assumption directly determines the effectiveness of the model to expand $t_{\text {crit }}$ for positively segmented species. Therefore, if this assumption is invalid, $t_{\text {crit }}$ may be critically overestimated. For instance, Wolfe et al. (2016) have shown for one out of six species that leaf shedding was not associated with a protection against a water potential drop in a tropical dry forest.
To our knowledge, no study has monitored the water mass loss of a shoot or a branch preceding and following leaf xylem embolism or leaf shedding. It is probable that some remaining water losses occur at the leaf level, even if leaf minimum transpiration is strongly reduced after leaf embolism. It would be beneficial if future studies would monitor total transpiration flow of whole shoots or branches, over desiccation time, to empirically assess if the hypothesised mechanism behind segmentation (reduction of the evaporative surface due to leaf embolism) is true.

Second, stem desiccation may start before leaf hydraulic failure, which may impact the estimation of $t_{\text {crit }}$. For instance, a recent study has suggested that pressure-driven embolism spreading is not the exclusive mechanism of embolism spreading, but that pre-existing embolism may also be determinant (Guan et al. 2020). Such pre-existing embolism has been shown to be more likely in large and long vessels characterising stems rather than leaves.

Third, the loss of evaporative surface, either driven by leaf embolism or leaf shedding, can be progressive and gradual in space and time, rather than sudden as assumed 
Table 3 Relationships between the constitutive traits of $t_{\text {crit }}$ model and the $t_{\text {crit }}$ output

\begin{tabular}{|c|c|c|c|c|}
\hline \multirow[t]{2}{*}{ Predictor } & \multicolumn{2}{|c|}{ All species } & \multicolumn{2}{|c|}{$\begin{array}{l}\text { Segmented spe- } \\
\text { cies only }\end{array}$} \\
\hline & $R^{2}$ & $P$-value & $\overline{R^{2}}$ & $P$-value \\
\hline $\mathrm{P}_{88, \text { leaf }}-\mathrm{P}_{88, \text { stem }}$ & 0.842 & $<0.001$ & 0.776 & $<0.001$ \\
\hline$\Psi_{\text {tlp }}-\mathrm{P}_{88, \text { leaf }}$ & 0.782 & $<0.001$ & 0.769 & $<0.001$ \\
\hline $\mathrm{P}_{88 \text {,stem }}$ & 0.711 & $<0.001$ & 0.581 & $<0.01$ \\
\hline$g_{\text {bark }}$ & 0.155 & 0.108 & 0.020 & 0.667 \\
\hline $\mathrm{P}_{88 \text {,leaf }}$ & 0.143 & 0.130 & 0.240 & 0.110 \\
\hline$A_{\text {leaf }}$ & 0.131 & 0.140 & 0.275 & 0.084 \\
\hline$A_{\text {leaf }}-A_{\text {bark }}$ & 0.131 & 0.140 & 0.275 & 0.084 \\
\hline$C_{\text {stem }} A_{\text {bark }}{ }^{-1}-C_{\text {shoot }} A_{\text {leaf +bark }}{ }^{-1}$ & 0.111 & 0.176 & 0.290 & 0.075 \\
\hline$C_{\text {stem }} A_{\text {bark }}^{-1}$ & 0.097 & 0.209 & 0.283 & 0.075 \\
\hline$g_{\min }-g_{\text {bark }}$ & 0.085 & 0.239 & 0.220 & 0.128 \\
\hline$V_{\text {stem }}$ & 0.081 & 0.253 & 0.283 & 0.115 \\
\hline$W_{\mathrm{ft}, \mathrm{stem}} * V_{\mathrm{stem}}$ & 0.071 & 0.283 & 0.213 & 0.134 \\
\hline$W_{\text {tlp,leaf }} * A_{\text {leaf }}$ & 0.059 & 0.331 & 0.047 & 0.499 \\
\hline$g_{\min } * 2 A_{\text {leaf }}$ & 0.056 & 0.344 & 0.063 & 0.430 \\
\hline$A_{\text {bark }}$ & 0.026 & 0.519 & 0.020 & 0.667 \\
\hline$C_{\text {shoot }} A_{\text {leaf }+ \text { bark }}{ }^{-1}$ & 0.019 & 0.580 & 0.013 & 0.733 \\
\hline$g_{\text {min }} * 2 A_{\text {leaf }}-g_{\text {bark }} * A_{\text {bark }}$ & 0.012 & 0.662 & 0.005 & 0.834 \\
\hline$W_{\text {tlp,leaf }}$ & 0.012 & 0.662 & 0.063 & 0.430 \\
\hline$\Psi_{\text {tlp }}$ & 0.003 & 0.818 & 0.004 & 0.852 \\
\hline$W_{\mathrm{ft}, \mathrm{stem}}$ & 0.002 & 0.869 & 0.099 & 0.320 \\
\hline$g_{\min }$ & 0.002 & 0.852 & 0.020 & 0.667 \\
\hline$g_{\text {bark }} * A_{\text {bark }}$ & 0.000 & 1.000 & 0.022 & 0.651 \\
\hline
\end{tabular}

Predictors are ordered by $R^{2}$ for all species. $R^{2}$ and $P$-values are shown in bold type for significant relationships. All acronyms are listed in Table 1

by the model. This has been shown for leaf shedding by Blackman et al. (2019b), and for leaf shedding mediated by vulnerability segmentation by Hochberg et al. (2017). In case of progressive leaf shedding mediated by vulnerability segmentation of grapevine (Hochberg et al. 2017), it implies that $\mathrm{P}_{\text {crit,leaf }}$ exhibits a certain degree of variation within a species, a crown, or a shoot, which has been properly demonstrated for Persea americana (Cardoso et al. 2020). However, our current model assumes a homogenous $P_{\text {crit,leaf }}$ across leaves. Not taking into account such progressive loss of evaporative surface in our model may overestimate $t_{\text {crit }}$. Therefore, future investigations should (i) try to quantify intra-branch or intra-crown $P_{50 \text {, leaf }}$ variability, and (ii) to monitor the kinetics of leaf embolism or shedding over time, and its impact on desiccation time across species.

\subsection{How does leaf-stem vulnerability segmentation expand shoot desiccation time?}

Positively segmented species are species for which leaf xylem is more vulnerable to embolism than stem xylem
(Fig. 3a), which increases shoot desiccation time (Fig. 2s, b). Across those species, the shoot leaf area is 30 -fold higher than the stem bark area (Fig. 3c), but there is no difference between leaf minimum conductance and bark conductance (Fig. 3b). At the shoot level, the difference between leaf and bark surface area is sufficient to drive a cross-species difference in transpiration rate between the leaf compartment and the bark compartment (Fig. 3d). These findings suggest that the effect of vulnerability segmentation on $t_{\text {crit }}$ is largely driven by the difference in evaporative surface between leaf and bark, and not by any difference in conductance.

Bark conductance is not particularly low, as it is not different from $g_{\min }$, with a mean of $4.29 \mathrm{mmol} \mathrm{m}^{-2} \mathrm{~s}^{-1}$. This is comparable to the $g_{\min }$ mean of $4.90 \mathrm{mmol} \mathrm{m}^{-2} \mathrm{~s}^{-1}$ found by Duursma et al. (2019) across 221 species based on a meta-analysis. This is also in agreement with $g_{\text {bark }}$ measurements of Wolfe (2020) across eight tropical tree species $\left(0.86-12.98 \mathrm{mmol} \mathrm{m}^{-2} \mathrm{~s}^{-1}\right)$. On the one hand, at the shoot level, bark surface represents a small fraction of the total evaporative surface. However, for larger levels (i.e. branch, trunk), the leaf area-to-bark area ratio may decrease, as the leaf area to stem volume ratio generally decreases with tree size (Scholz et al. 2011). At these levels, bark area in combination with $g_{\text {bark }}$ may drive a larger fraction of the total plant transpiration, further playing a more important role on $t_{\text {crit }}$. On the other hand, $g_{\text {bark }}$ may be prone to dramatic ontogenetic effects by secondary growth (Lendzian 2006; Paine et al. 2010). In the present study, $g_{\text {bark }}$ measurements were based on relatively young stems, of ca. $0.5-$ to $1-\mathrm{cm}$ diameter. At this stage, the bark is relatively thin, even green and poorly lignified for some species, and may be a photosynthetic tissue (Santiago et al. 2016). As the tree grows in diameter, the cortex and the periderm become thicker. Therefore, for large trees, lower $g_{\text {bark }}$ may alleviate the effect of bark transpiration on $t_{\text {crit }}$ despite a larger bark surface. Future work should incorporate $g_{\text {bark }}$ measurements, potential ontogenetic effects, and assess the sensitivity of the model to these parameters ( $g_{\text {bark }} ; A_{\text {leaf }}$-to- $A_{\text {bark }}$ ratio) when scaling up, from shoot to branch to tree levels.

The difference between shoot and stem capacity per evaporative surface is not related to $t_{\text {crit }}$ (Fig. 4d), but there is a tendency of positive relationship if we consider $P<0.1$. This tendency along with the dramatic shift following leaf embolism (Fig. 3e) suggests that the capacity per unit of evaporative surface is a strong determinant of $t_{\text {crit }}$ at the shoot level. However, this may be partly explained by the fact that the capacity per evaporative surface is explicit in the $t_{\text {crit }}$ formula. At the shoot level, stem volume and thus the amount stored water are relatively small. It is well known that stem volume and total stem water content to leaf area ratio increase with plant size (Scholz et al. 2011). Therefore, the role of capacitance and water reservoirs in controlling $t_{\text {crit }}$ should be more important for adult canopy trees 
Fig. 3 Leaf-stem comparison in traits underlying vulnerability segmentation for the 12 species with a positive vulnerability segmentation $\left(P_{88, \text { leaf }}>P_{88 \text {,stem }}\right)$. a Comparison in $P_{88}$ between leaf and stem across species. b Comparison in minimum conductance between leaf $\left(g_{\text {min }}\right)$ and bark ( $\left.g_{\text {bark }}\right)$ across species. c Comparison in surface area between leaves and bark across species. d Comparison between total transpiration between leaves and bark across species. e Comparison in capacity per evaporative area between the entire shoot (leaf + stem) and stem only. Leaf surface area is multiplied by two as both abaxial and adaxial sides are evaporative. All abbreviations are presented in Table 1
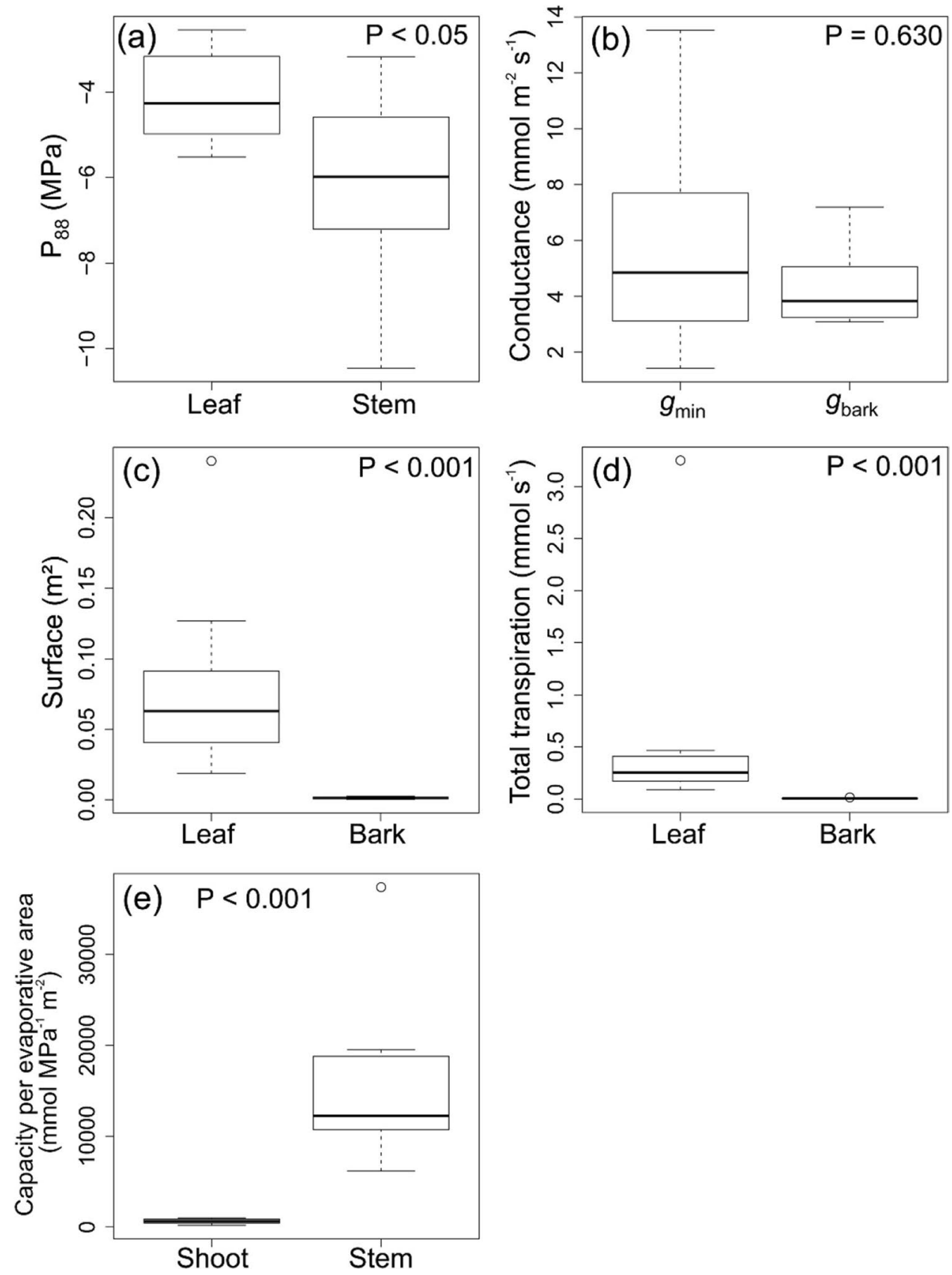

for which wood volume represents several cubic meters. Moreover, here we considered the shoot as hydraulically independent and separated from the rest of the tree, whereas capacitive effects of upstream organs such as branches and the trunk may have a role in supplying water to the shoot, which would then expand the shoot desiccation time. Hence, it is critical to scale-up $t_{\text {crit }}$ estimations at higher levels, such as the whole-tree level. However, this is challenging as it will require data on crown area, volume of capacitive wood, and even root traits (Martin-StPaul et al. 2017), which is particularly difficult to measure or estimate for tall tropical rainforest trees.
Overall, we found consistent cross-species differences in key parameters (xylem embolism resistance, surface area, total transpiration, capacity per evaporative area) between leaves and stems (Fig. 3c-e). However, we did not find tight relationships between the leaf-stem difference in these parameters and $t_{\text {crit }}$ (Fig. 4), except for embolism resistance. First, this supports the degree of vulnerability segmentation to be the leading parameter in determining $t_{\text {crit }}$. Second, this does not necessary suggest that other parameters are not significant determinants, but it could be that the relative contribution of these parameters may vary depending on the species. In other words, the effect 
Fig. 4 Relationships between shoot desiccation time and drought resistance traits for the 12 species with a positive vulnerability segmentation $\left(P_{88, \text { leaf }}>P_{88 \text {,stem }}\right)$. a Shoot desiccation time according to the leaf-bark difference in minimum conductance. b Shoot desiccation time according to the leaf-bark difference in surface area. c Shoot desiccation time according to the leaf-bark difference in evapotranspiration. d Shoot desiccation time according to the total shoot vs. stem capacity per total evaporative surface area. Leaf surface area is multiplied by two as both abaxial and adaxial sides are evaporative. All abbreviations are presented in Table 1
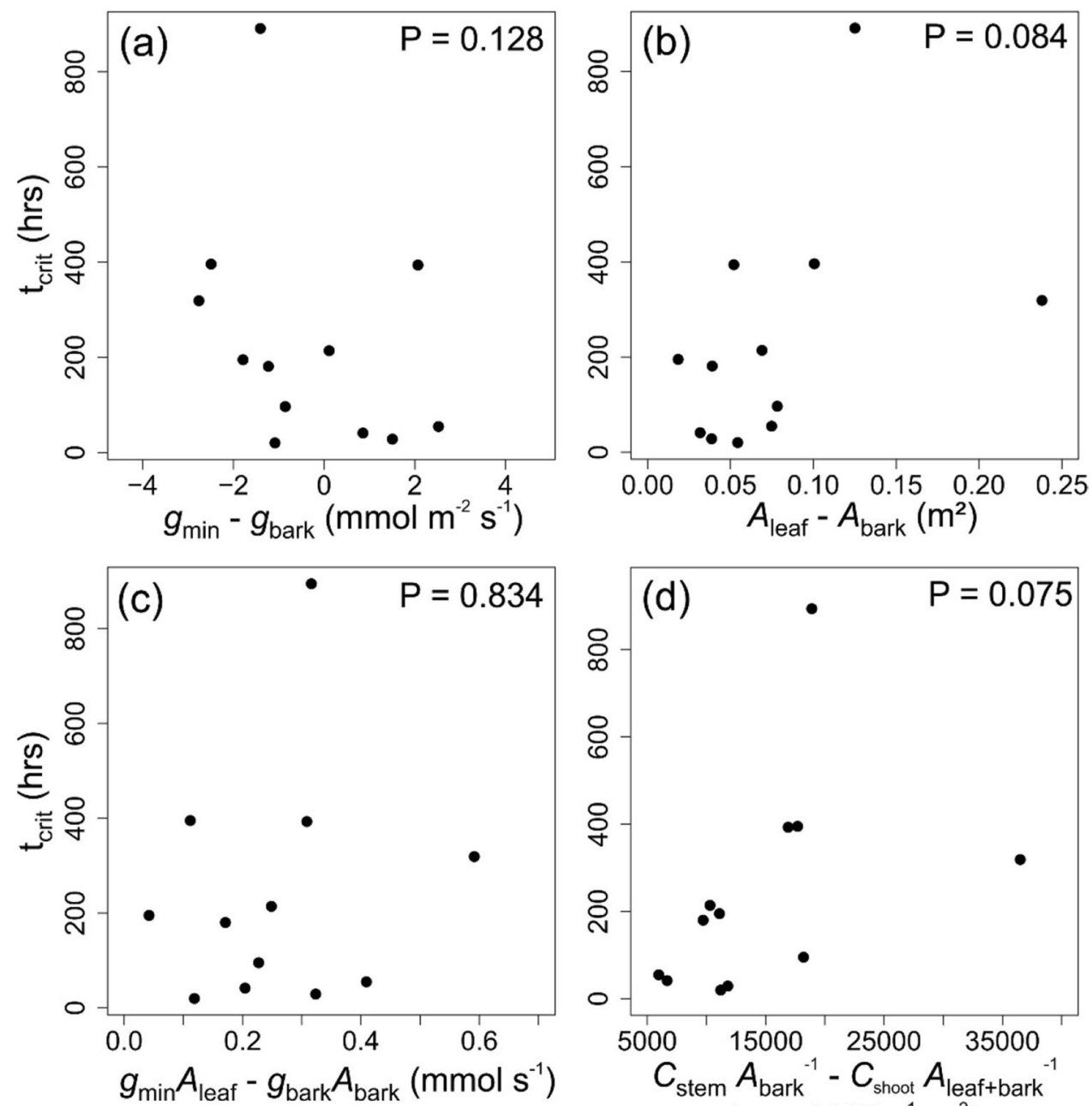

of interactions between parameters into the model may blur a direct relationship between a given trait and $t_{\text {crit }}$. Third, the relative contribution of the different parameters may also be sensitive to the focused level of organisation (i.e. shoot, branch, whole plant). Therefore, more experimental (such as Blackman et al., 2019b) and theoretical (such as this present study) measurements of $t_{\text {crit }}$ are required to better identify (i) the relative contribution of parameters behind the effectiveness of vulnerability segmentation on $t_{\text {crit }}$, and (ii) the relative contribution of traits determining $t_{\text {crit }}$ and drought resistance in general, which is critical for parsimonious but powerful parameterisations of models to predict plant drought resistance and future vegetation dynamics under climate change (McDowell et al. 2018; Brodribb et al. 2020).

\section{Conclusion}

In this present study, we investigated the effect of leaf-stem vulnerability segmentation on shoot $t_{\text {crit }}$, as also the potential mechanisms by which vulnerability segmentation allows to expand $t_{\text {crit }}$.
This study reports two important findings. (1) Vulnerability segmentation theoretically expands shoot $t_{\text {crit }}$, suggesting that vulnerability segmentation is an important drought resistance mechanism. (2) Increasing $t_{\text {crit }}$ is mostly driven by the difference in evaporative surface between leaf and bark-not by the difference between $g_{\min }$ and $g_{\text {bark }}$-and potentially the difference between shoot and stem capacity per evaporative surface. Consequently, we suggest that future trait-based assessments of plant drought resistance should incorporate vulnerability segmentation, to avoid underestimations of plant drought resistance. This is particularly required in the perspective of individual-based modelling aiming at predicting vegetation dynamics under different climate change scenarios. As plant drought resistance remains difficult to quantify, the trait-based model used in the present study is promising, but requires (i) further tests on the model assumptions, especially regarding the incorporation of vulnerability segmentation, (ii) comparisons with experimental $t_{\text {crit }}$ measurements and more mechanistic models (e.g. SurEau; Cochard et al. 2020)), and (iii) investigations and improvements to allow whole-tree level upscaling, which is an important issue for tropical rainforest canopy trees. 
Supplementary Information The online version contains supplementary material available at https://doi.org/10.1007/s13595-021-01094-9.

Acknowledgements We thank the climbing team for canopy sampling: Jocelyn Cazal, Valentine Alt, Samuel Counil, Anthony Percevaux, and Elodie Courtois. We thank the following colleagues for technical assistance during field work: Oscar Affholder, Louise Authier, Anne Baranger, Maxime Bellifa, Benoit Burban, Maëlle Cario, Bruno Clair, Maxime Corbin, Elia Dardevet, Alexandre De Haldat Du Lys, Emilien Fort, Frederic Fung Fong You, Eva Gril, Thomas Saint-Germain, and Ruth Tchana Wandji. We would like to thank the Paracou Research Station managed by CIRAD for tree sampling. We also would like to thank the SILVATECH (Silvatech, INRAE, 2018. Structural and functional analysis of tree and wood Facility, https://doi.org/10.15454/1.5572400113627854E12) from UMR 1434 SILVA, 1136 IAM, 1138 BEF, and 4370 EA LERMAB EEF research centre INRAE Nancy-Lorraine for support with anatomical sectioning. The SILVATECH facility is supported by the French National Research Agency through the Laboratory of Excellence ARBRE (ANR-11-LABX-0002-01). We also would like to thank the PHENOBOIS platform for embolism resistance measurements (PHENOBOIS, Bordeaux France).

Author contribution S.L, S.C, and P.H. designed the study; S.L, C.Z., S.C., C.S., E.C., J.-Y.G., and P.H. collected field samples; S.L., C.Z., S. C., D.B., J.-Y.G, and E.C. performed measurements or provided data; S.L. and C.Z. performed data analysis; S.L. wrote the manuscript with contribution of C.Z., S.J., P.H., and S.C; all authors discussed the results and contributed valuable comments on the manuscript.

Funding This study was funded by the GFclim project (FEDER 20142020, Project GY0006894). This work has benefited from an "Investissement d'Avenir" grant managed by Agence Nationale de la Recherche (CEBA, ref. ANR-10-LABX-25-01). S.L. was supported by a doctoral fellowship from CEBA.

Data availability The datasets generated during the current study are available from the corresponding author on reasonable request.

\section{Declarations}

Ethical approval All procedures performed in studies involving human participants were in accordance with the ethical standards of the institutional and/or national research committee and with the 1964 Helsinki declaration and its later amendments or comparable ethical standards.

Conflict of interest The authors declare no competing interests.

Open Access This article is licensed under a Creative Commons Attribution 4.0 International License, which permits use, sharing, adaptation, distribution and reproduction in any medium or format, as long as you give appropriate credit to the original author(s) and the source, provide a link to the Creative Commons licence, and indicate if changes were made. The images or other third party material in this article are included in the article's Creative Commons licence, unless indicated otherwise in a credit line to the material. If material is not included in the article's Creative Commons licence and your intended use is not permitted by statutory regulation or exceeds the permitted use, you will need to obtain permission directly from the copyright holder. To view a copy of this licence, visit http://creativecommons. org/licenses/by/4.0/.

\section{References}

R Core Team (2018) R: a language and environment for statistical computing. https://www.gbif.org/fr/tool/81287/r-a-language-and-envir onment-for-statistical-computing. Accessed 15 Feb 2021

Aguilos M, Stahl C, Burban B et al (2019) Interannual and seasonal variations in ecosystem transpiration and water use efficiency in a tropical rainforest. Forests 10:20

Aleixo I, Norris D, Hemerik L et al (2019) Amazonian rainforest tree mortality driven by climate and functional traits. Nat Clim Chang 9:384-388. https://doi.org/10.1038/s41558-019-0458-0

Allen CD, Macalady AK, Chenchouni H et al (2010) A global overview of drought and heat-induced tree mortality reveals emerging climate change risks for forests. For Ecol Manag 259:660-684. https://doi.org/10.1016/j.foreco.2009.09.001

Bartlett MK, Klein T, Jansen S et al (2016) The correlations and sequence of plant stomatal, hydraulic, and wilting responses to drought. PNAS 113:13098-13103. https://doi.org/10.1073/pnas. 1604088113

Blackman CJ, Pfautsch S, Choat B et al (2016) Toward an index of desiccation time to tree mortality under drought. Plant Cell Environ 39:2342-2345. https://doi.org/10.1111/pce.12758

Blackman CJ, Creek D, Maier C et al (2019a) Drought response strategies and hydraulic traits contribute to mechanistic understanding of plant dry-down to hydraulic failure. Tree Physiol 39:910-924. https://doi.org/10.1093/treephys/tpz016

Blackman CJ, Li X, Choat B et al (2019b) Desiccation time during drought is highly predictable across species of Eucalyptus from contrasting climates. New Phytol 224:632-643. https://doi.org/ 10.1111/nph.16042

Brienen RJW, Phillips OL, Feldpausch TR et al (2015) Long-term decline of the Amazon carbon sink. Nature 519:344-348. https://doi.org/10.1038/nature14283

Brienen RJW, Caldwell L, Duchesne L et al (2020) Forest carbon sink neutralized by pervasive growth-lifespan trade-offs. Nat Commun 11:4241. https://doi.org/10.1038/s41467-020-17966-Z

Brodribb TJ, Cochard H (2009) Hydraulic failure defines the recovery and point of death in water-stressed conifers. Plant Physiol 149:575-584. https://doi.org/10.1104/pp.108.129783

Brodribb TJ, Holbrook NM, Edwards EJ, Gutiérrez MV (2003) Relations between stomatal closure, leaf turgor and xylem vulnerability in eight tropical dry forest trees. Plant Cell Environ 26:443-450. https://doi.org/10.1046/j.1365-3040.2003.00975.x

Brodribb TJ, Bienaimé D, Marmottant P (2016a) Revealing catastrophic failure of leaf networks under stress. PNAS 113:48654869. https://doi.org/10.1073/pnas.1522569113

Brodribb TJ, Skelton RP, McAdam SAM et al (2016b) Visual quantification of embolism reveals leaf vulnerability to hydraulic failure. New Phytol 209:1403-1409. https://doi.org/10.1111/nph.13846

Brodribb TJ, Powers J, Cochard H, Choat B (2020) Hanging by a thread? Forests and drought. Science 368:261-266. https://doi. org/10.1126/science.aat7631

Brum M, Vadeboncoeur MA, Ivanov V et al (2019) Hydrological niche segregation defines forest structure and drought tolerance strategies in a seasonal Amazon forest. J Ecol 107:318-333. https://doi.org/10.1111/1365-2745.13022

Cardoso AA, Batz TA, McAdam SAM (2020) Xylem embolism resistance determines leaf mortality during drought in Persea americana. Plant Physiol 182:547-554. https://doi.org/10.1104/ pp. 19.00585

Charrier G, Torres-Ruiz JM, Badel E et al (2016) Evidence for hydraulic vulnerability segmentation and lack of xylem refilling under tension. Plant Physiol 172:1657-1668. https://doi.org/ 10.1104/pp.16.01079 
Chen J-W, Zhang Q, Li X-S, Cao K-F (2009) Independence of stem and leaf hydraulic traits in six Euphorbiaceae tree species with contrasting leaf phenology. Planta 230:459-468. https://doi.org/ 10.1007/s00425-009-0959-6

Chen J-W, Zhang Q, Li X-S, Cao K-F (2010) Gas exchange and hydraulics in seedlings of Hevea brasiliensis during water stress and recovery. Tree Physiol 30:876-885. https://doi.org/10.1093/ treephys/tpq043

Cochard H, Pimont F, Ruffault J, Martin-StPaul N (2020) SurEau.c : a mechanistic model of plant water relations under extreme drought. bioRxiv 2020.05.10.086678. https://doi.org/10.1101/ 2020.05.10.086678

DeSoto L, Cailleret M, Sterck F et al (2020) Low growth resilience to drought is related to future mortality risk in trees. Nat Commun 11:545. https://doi.org/10.1038/s41467-020-14300-5

Duffy PB, Brando P, Asner GP, Field CB (2015) Projections of future meteorological drought and wet periods in the Amazon. PNAS 112:13172-13177. https://doi.org/10.1073/pnas.1421010112

Duursma RA, Blackman CJ, Lopéz R et al (2019) On the minimum leaf conductance: its role in models of plant water use, and ecological and environmental controls. New Phytol 221:693-705. https://doi.org/10.1111/nph.15395

Esquivel-Muelbert A, Baker TR, Dexter KG et al (2019) Compositional response of Amazon forests to climate change. Global Change Biol 25:39-56. https://doi.org/10.1111/gcb.14413

Gourlet-Fleury S, Guehl JM, Laroussine O (2004) Ecology and management of a neotropical rainforest : lessons drawn from Paracou, a long-term experimental research site in French Guiana. Elsevier, Paris

Guan X, Pereira L, McAdam SAM et al (2020) No gas source, no problem: Proximity to pre-existing embolism and segmentation affect embolism spreading in angiosperm xylem by gas diffusion. Plant Cell Environ. https://doi.org/10.1111/pce.14016

Hochberg U, Albuquerque C, Rachmilevitch S et al (2016) Grapevine petioles are more sensitive to drought induced embolism than stems: evidence from in vivo MRI and microcomputed tomography observations of hydraulic vulnerability segmentation. Plant Cell Environ 39:1886-1894. https://doi.org/10.1111/pce.12688

Hochberg U, Windt CW, Ponomarenko A et al (2017) Stomatal closure, basal leaf embolism, and shedding protect the hydraulic integrity of grape stems. Plant Physiol 174:764-775. https://doi. org/10.1104/pp.16.01816

Johnson DM, Wortemann R, McCulloh KA et al (2016) A test of the hydraulic vulnerability segmentation hypothesis in angiosperm and conifer tree species. Tree Physiol 36:983-993. https://doi. org/10.1093/treephys/tpw031

Jupa R, Plavcová L, Gloser V, Jansen S (2016) Linking xylem water storage with anatomical parameters in five temperate tree species. Tree Physiol 36:756-769. https://doi.org/10.1093/treep hys/tpw020

Klepsch M, Zhang Y, Kotowska MM et al (2018) Is xylem of angiosperm leaves less resistant to embolism than branches? Insights from microCT, hydraulics, and anatomy. J Exp Bot 69:56115623. https://doi.org/10.1093/jxb/ery321

Koide RT, Robichaux RH, Morse SR, Smith CM (1989) Plant water status, hydraulic resistance and capacitance. In: Pearcy RW, Ehleringer JR, Mooney HA, Rundel PW (eds) Plant physiological ecology: field methods and instrumentation. Springer, Netherlands, Dordrecht, pp 161-183

Lendzian KJ (2006) Survival strategies of plants during secondary growth: barrier properties of phellems and lenticels towards water, oxygen, and carbon dioxide. J Exp Bot 57:2535-2546. https://doi.org/10.1093/jxb/er1014

Levionnois S, Ziegler C, Jansen S et al (2020) Vulnerability and hydraulic segmentations at the stem-leaf transition: coordination across Neotropical trees. New Phytol 228:512524. https://doi.org/10.1111/nph.16723

Li S, Feifel M, Karimi Z et al (2016) Leaf gas exchange performance and the lethal water potential of five European species during drought. Tree Physiol 36:179-192. https://doi.org/10.1093/treep hys/tpv 117

Li X, Delzon S, Torres-Ruiz J et al (2020) Lack of vulnerability segmentation in four angiosperm tree species: evidence from direct X-ray microtomography observation. Ann for Sci 77:37. https://doi.org/10.1007/s13595-020-00944-2

Martin-StPaul N, Delzon S, Cochard H (2017) Plant resistance to drought depends on timely stomatal closure. Ecol Lett 20:14371447. https://doi.org/10.1111/ele.12851

Mcculloh KA, Johnson DM, Meinzer FC, Woodruff DR (2014) The dynamic pipeline: hydraulic capacitance and xylem hydraulic safety in four tall conifer species. Plant Cell Environ 37:11711183. https://doi.org/10.1111/pce. 12225

McDowell N, Allen CD, Anderson-Teixeira K et al (2018) Drivers and mechanisms of tree mortality in moist tropical forests. New Phytol 219:851-869. https://doi.org/10.1111/nph.15027

Paine CET, Stahl C, Courtois EA et al (2010) Functional explanations for variation in bark thickness in tropical rain forest trees. Funct Ecol 24:1202-1210. https://doi.org/10.1111/j.1365-2435. 2010.01736.x

Resco V, Ewers BE, Sun W et al (2009) Drought-induced hydraulic limitations constrain leaf gas exchange recovery after precipitation pulses in the C3 woody legume, Prosopis velutina. New Phytol 181:672-682. https://doi.org/10.1111/j.1469-8137.2008.02687.x

Rodriguez-Dominguez CM, Buckley TN, Egea G et al (2016) Most stomatal closure in woody species under moderate drought can be explained by stomatal responses to leaf turgor. Plant Cell Environ 39:2014-2026. https://doi.org/10.1111/pce.12774

Rodriguez-Dominguez CM, Murphy MRC, Lucani C, Brodribb TJ (2018) Mapping xylem failure in disparate organs of whole plants reveals extreme resistance in olive roots. New Phytol 218:1025-1035. https://doi.org/10.1111/nph.15079

Roth I (1981) Structural patterns of tropical barks. Borntraeger

Santiago LS, Bonal D, De Guzman ME, Ávila-Lovera E (2016) Drought survival strategies of tropical trees. In: Goldstein G, Santiago LS (eds) Tropical tree physiology: adaptations and responses in a changing environment. Springer, Cham, pp 243-258

Santiago LS, Guzman MED, Baraloto C et al (2018) Coordination and trade-offs among hydraulic safety, efficiency and drought avoidance traits in Amazonian rainforest canopy tree species. New Phytol 218:1015-1024. https://doi.org/10.1111/nph.15058

Scholz FG, Phillips NG, Bucci SJ et al (2011) Hydraulic capacitance: biophysics and functional significance of internal water sources in relation to tree size. In: Meinzer FC, Lachenbruch B, Dawson TE (eds) Size- and age-related changes in tree structure and function. Springer, Dordrecht, pp 341-361

Skelton RP, Brodribb TJ, Choat B (2017) Casting light on xylem vulnerability in an herbaceous species reveals a lack of segmentation. New Phytol 214:561-569. https://doi.org/10.1111/ nph. 14450

Skelton RP, Dawson TE, Thompson SE et al (2018) Low vulnerability to xylem embolism in leaves and stems of North American Oaks. Plant Physiol 177:1066-1077. https://doi.org/10.1104/ pp.18.00103

Smith-Martin CM, Skelton RP, Johnson KM et al (2020) Lack of vulnerability segmentation among woody species in a diverse dry sclerophyll woodland community. Funct Ecol 34:777-787. https://doi.org/10.1111/1365-2435.13519

Tyree MT, Ewers FW (1991) The hydraulic architecture of trees and other woody plants. New Phytol 119:345-360. https://doi.org/ 10.1111/j.1469-8137.1991.tb00035.x 
Tyree MT, Sperry JS (1989) Vulnerability of xylem to cavitation and embolism. Annu Rev Plant Physiol Plant Mol Biol 40:19-36. https://doi.org/10.1146/annurev.pp.40.060189.000315

Tyree MT, Zimmermann MH (2002) Xylem structure and the ascent of sap, 2nd edn. Springer, Berlin

Urli M, Porté AJ, Cochard H et al (2013) Xylem embolism threshold for catastrophic hydraulic failure in angiosperm trees. Tree Physiol 33:672-683. https://doi.org/10.1093/treephys/ tpt030

Volaire F (2018) A unified framework of plant adaptive strategies to drought: crossing scales and disciplines. Global Change Biol 24:2929-2938. https://doi.org/10.1111/gcb.14062

Wolfe BT (2020) Bark water vapour conductance is associated with drought performance in tropical trees. Biol Lett 16:20200263. https://doi.org/10.1098/rsbl.2020.0263
Wolfe BT, Sperry JS, Kursar TA (2016) Does leaf shedding protect stems from cavitation during seasonal droughts? A test of the hydraulic fuse hypothesis. New Phytol 212:1007-1018. https:// doi.org/10.1111/nph.14087

Zhu S-D, Liu H, Xu Q-Y et al (2016) Are leaves more vulnerable to cavitation than branches? Funct Ecol 30:1740-1744. https://doi. org/10.1111/1365-2435.12656

Ziegler C, Coste S, Stahl C et al (2019) Large hydraulic safety margins protect Neotropical canopy rainforest tree species against hydraulic failure during drought. Ann for Sci 76:115. https:// doi.org/10.1007/s13595-019-0905-0

Publisher's note Springer Nature remains neutral with regard to jurisdictional claims in published maps and institutional affiliations.

\section{Authors and Affiliations}

\section{Sébastien Levionnois ${ }^{1,2}\left(\mathbb{D} \cdot\right.$ Camille Ziegler $^{1,3} \cdot$ Patrick Heuret $^{1,2} \cdot$ Steven Jansen $^{4} \cdot$ Clément Stahl $^{1} \cdot$ Emma Calvet $^{1}$. Jean-Yves Goret ${ }^{1} \cdot$ Damien Bonal $^{3} \cdot$ Sabrina Coste ${ }^{1}$}

Sébastien Levionnois

sebastien.levionnois.pro@gmail.com

Camille Ziegler

camille.ziegler9@gmail.com

Patrick Heuret

patrick.heuret@inrae.fr

Steven Jansen

steven.jansen@uni-ulm.de

Clément Stahl

clement.stahl@ecofog.gf

Emma Calvet

emma34380@gmail.com
Damien Bonal

damien.bonal@inrae.fr

1 UMR EcoFoG, AgroParisTech, CIRAD, CNRS,

INRAE, Université Des Antilles, Université de Guyane, 97310 Kourou, France

2 UMR AMAP, Univ. Montpellier, CIRAD, CNRS, INRAE, IRD, 34000 Montpellier, France

3 UMR Silva, Université de Lorraine, AgroParisTech, INRAE, 54000 Nancy, France

4 Institute of Systematic Botany and Ecology, Ulm University, 89081 Ulm, Germany 